Natural Hazards and Earth System Sciences (2002) 2: 27-35

(C) European Geophysical Society 2002

\title{
Influences of hydrological and hydrogeological conditions on debris flows in peri-vesuvian hillslopes
}

\author{
P. De Vita ${ }^{1}$ and V. Piscopo ${ }^{2}$ \\ ${ }^{1}$ Department of Geophysics and Volcanology, University of Naples "Federico II", Italy \\ ${ }^{2}$ Department of Environmental Sciences, University of Viterbo "La Tuscia", Italy
}

Received: 13 August 2001 - Revised: 8 January 2002 - Accepted: 16 January 2002

\begin{abstract}
The paper illustrates some results of research carried out to assess factors triggering debris flows which involve the pyroclastic overburdens covering carbonate mountains around Vesuvius. The aims of the research were to reconstruct a relationship between rainfall and debris flow occurrence and to highlight empirical hydrological thresholds through rainfall pattern analysis. The research was also aimed at investigating hydrogeological features of a pyroclastic cover-carbonate bedrock system to analyse factors inducing temporary hydraulic flow, critical for pyroclastic soil stability. The results of research are the following: i) rainfall pattern highlights empirical hydrological thresholds that differentiate the Lattari and Salerno Mountains from the Sarno Mountains; ii) in some sample areas of the Sarno Mountains close to the trigger zones of the landslides of May 1998 strong variation in hydraulic conductivity has been found in the first few meters below the surface; iii) these permeability variations would seem to justify temporary perched water tables that might affect the stability of the pyroclastic mantle.
\end{abstract}

Key words. Debris flows, pyroclastic overburdens, hydrological threshold, hydrogeological models

\section{Introduction}

The pyroclastic deposits overlying the carbonate mountains of the southern and eastern boundaries of the Campana Plain have been frequently involved in landslide phenomena. This kind of landslide triggers in the upper part of the slopes and subsequently develops as debris flow. The landslides that occurred on 5 and 6 May 1998 along the Pizzo d'Alvano Mountain may be included in this kind.

Previous research has highlighted the influences on the stability of the pyroclastic cover of the hydrological, stratigraphic, morphologic and hydrogeological conditions and physical and mechanical properties of deposits. Yet it has

Correspondence to: P. De Vita (leodev@oneonline.it) been observed that the genetic mechanism of these landslides cannot be generalised due to the variety of geological and geomechanical conditions that contribute to the stability of the pyroclastic cover on the carbonate slopes (Civita and Lucini, 1968; De Riso and Nota D’Elogio, 1973; Guida et al., 1974; Civita et al., 1975; Cascini and Versace, 1986; Celico et al., 1986; Guadagno et al., 1988; Guadagno, 1991; Calcaterra et al., 1997; De Falco et al., 1997; Celico and Guadagno, 1998; Del Prete et al., 1998).

It is in this context that the present study has been undertaken, aimed at examining influences of hydrological and hydrogeological conditions on landslide triggering causes. This has been made possible by studying both the results of recent research conducted by the Department of Geophysics and Volcanology - University of Naples "Federico II" (Celico et al., 2000; De Vita, 2000) and new data.

In order to achieve the aim, a study on two different scales has been conducted. On a large scale, the relationship between rainfall data and past landslide phenomena occurring on the carbonate slopes of the Lattari, Sarno and Salerno Mountains has been examined. On a small scale, significant hydrogeological situations on the Pizzo d'Alvano Mountain, the area heavily affected by landslides in May 1998, have been examined. In particular, in this study the conditions leading to the formation of a perched water table, hypothesised as a trigger of initial slides, are assessed. The aims of this work are thus the analysis of hydrogeological features of surficial aquifers and individuation from historical cases of rainfall thresholds that caused debris flows.

\section{Study area and geological layout}

The geological features of the area can be schematically outlined in a meso-cenozoic substratum represented by carbonate sedimentary sequences belonging to a paleogeographic unit deformed by Miocene orogenic phases. At present, the sedimentary sequences constitute the carbonate mountains (Lattari, Salerno and Sarno Mountains) surrounding Vesu- 


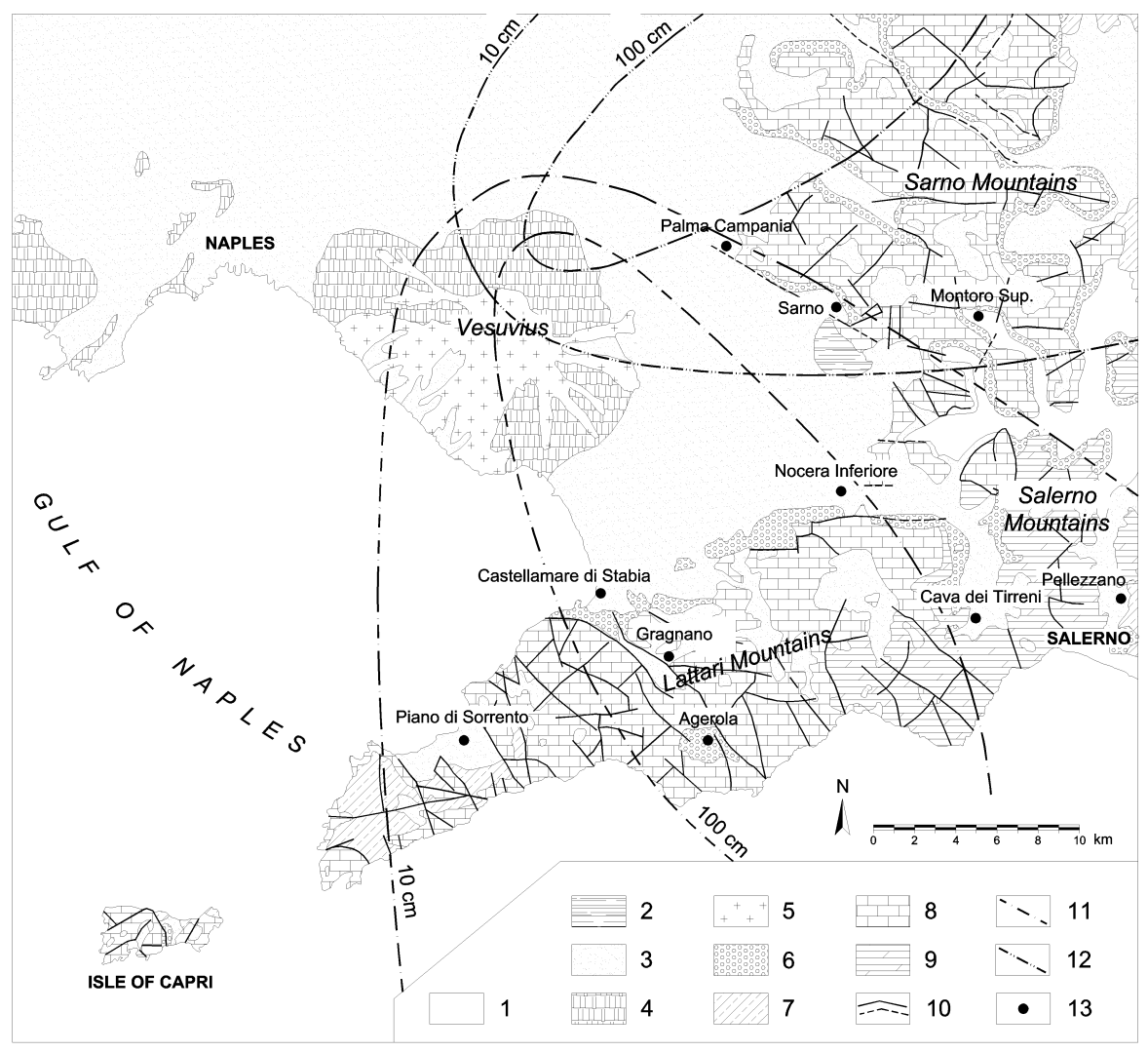

Fig. 1. Geological sketch of perivesuvian area: 1) alluvial deposits; 2) travertine; 3) incoherent ash-fall pyroclastic deposits in primary deposition and transported; 4) mainly coherent pyroclatic deposits of base surge; 5) lavas; 6) detritus and talus deposits; 7) Miocene flysch deposits; 8) middle Jurassic-Upper Cretaceous limestones; 9) lower Triassic-Middle Jurassic dolomites and calcareous limestones; 10) outcropping and buried faults; 11) isopachous lines (centimetres) of $79 \mathrm{AD}$ eruption; 12) isopachous lines (centimetres) of 1800 BC eruption; 13) raingauge stations. vius (Fig. 1). Large-scale morphology and position of these mountains was induced chiefly by Pleistocene extensional tectonic phases in which the eastern side of the original carbonate blocks was sunk by a complex system of tensional faults, forming a semi-graben structure. In the central part of this structural depression the volcanic activity began from different eruptive centres: Ischia Island (150 k-year BP 1302 AD), Phlegraean Fields (37 k-year BP $\div 1538$ AD) and Somma-Vesuvius ( $25 \mathrm{k}$-year BP $\div 1944 \mathrm{AD})$. The structural depression was filled by alluvial and volcanic deposits and now corresponds to the Campana Plain, a very large, flat area. Base-surge and ash-fall pyroclastic deposits, derived from Somma-Vesuvius eruptions (the most important being $1800 \mathrm{BC}$ and $79 \mathrm{AD}$ ), mantled areas surrounding the volcano (Fig. 1) and thus also the carbonate slopes. In this geomorphological context, especially in steep slopes, pyroclastic overburdens are subject to initial sliding, induced by particular hydrological conditions and evolving downwards as debris flow. This kind of landslide includes the disastrous phenomena, which occurred on the Sarno Mountains in May 1998.

\section{Analysis of hydrological conditions triggering debris flows}

The initial slope instabilities that evolve downwards in debris flows, occurring on the pyroclastic overburdens mantling slopes of the Lattari, Sarno and Salerno Mountains, were triggered by rainfall. It is a cause-effect relation that is commonly recognised. Thus, one aim of this research was to evaluate thresholds of hydrologic parameters that trigger landslides, such as rainfall pattern, and antecedent soil hydrology conditions. The analysis was conducted in order to collect and to validate data regarding historical debris flow occurrence, already recognised by the AVI archive (Guzzetti, et al., 1994) and by other sources, like regional newspapers (chiefly "Il Mattino") and unpublished technical documents (chiefly from ANAS, the Italian department of road maintenance). The acquisition of daily rainfall data, from the nearest and most reliable raingauge stations, completed the historical debris flow collection: rainfall data regarding the day of each landslide occurrence $(\mathrm{P})$ and the antecedent days were collected (Table 1). Twenty-six notices of debris flow occurrence were found which are distributed as follows: 19 for the Lattari Mountains, 6 for the Sarno Mountains and 1 for the Salerno Mountains. Each occurrence has often been noticed as a singular phenomenon, in relation to damage caused in human activities, although the same event generated many debris flows spread across many inhabited slopes. The events of winter 1996-1997, for example, (known by chronicle only with c. 1 and c. 2 notices, in Table 1) extended their disastrous effects to many other inhabited areas of the Sorrentina Peninsula (Calcaterra et al., 1997). In this way, some notices of singular occurrence of debris flows could correspond to many other phenomena. However, rainfall data 
Table 1. Debris flow occurrences in pyroclastic overburdens known from chronicles and other technical documents (database AVI and other sources)

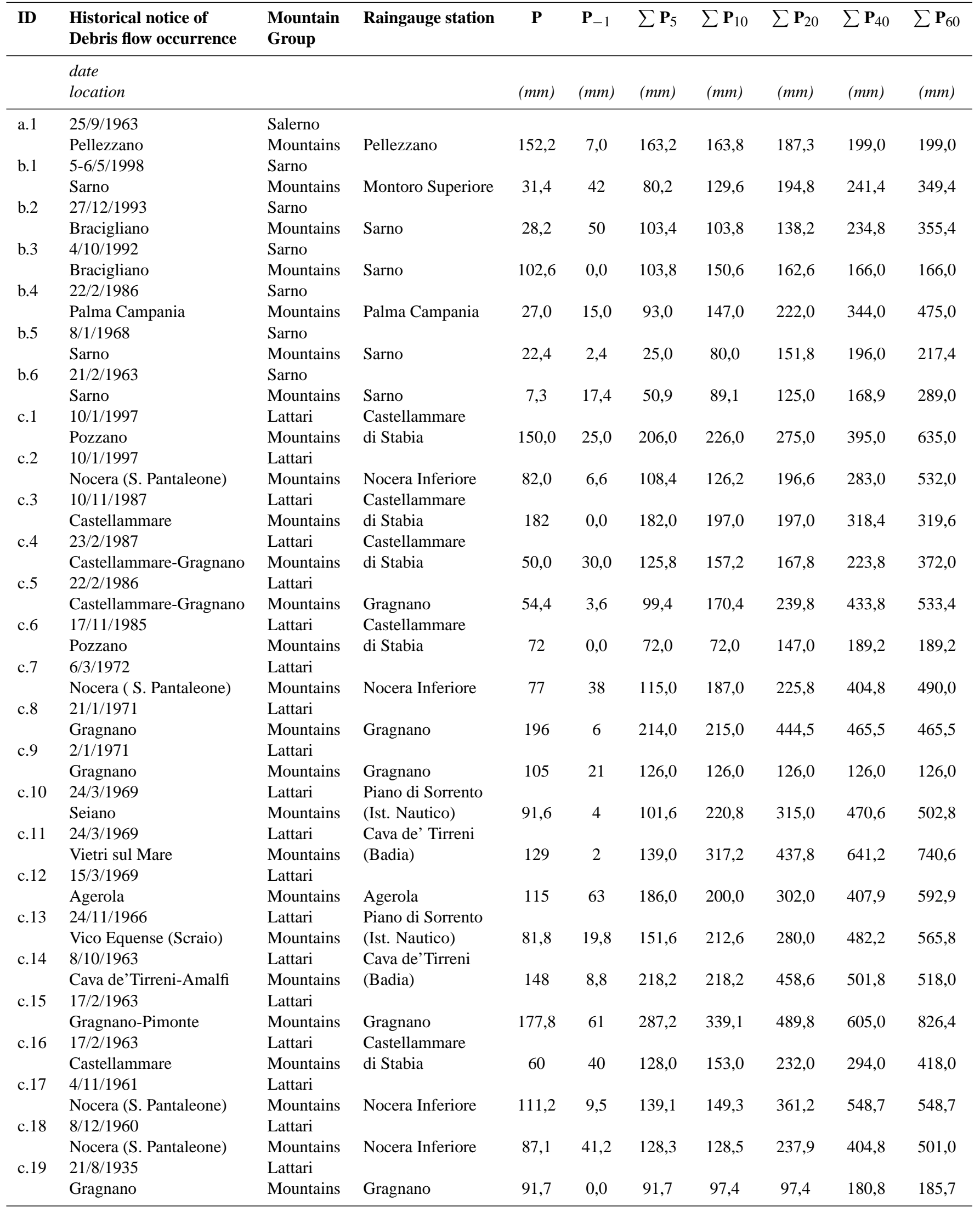


are obtained from raingauge stations nearest to locations of notices (Fig. 1).

The initial landslides, preceding the debris flows, consist of surficial debris slides involving low thickness of pyroclastic soils. For this reason the hydrological triggering cause of the landslide was investigated on the day of the event rainfall, namely the record of lowest duration available from rainfall data. In actual fact, rapid variation of pore pressure in medium permeability surficial aquifers can be caused by short duration, high intensity rainfall (Cascini and Versace, 1986). The predisposing hydrological cause, on the other hand, which increases water content before the day of the event, was investigated on antecedent days, with periods of different duration being checked.

From daily rainfall sequences the following parameters have been assessed: a) rainfall on the day of the event $(\mathbf{P}) ;$ b) rainfall on the day antecedent to the event $\left(\mathbf{P}_{-1}\right)$; c) cumulative rainfall on the days antecedent to the landslide, including the day of the event, referred to as different periods: 5 days $\left(\sum \mathbf{P}_{5}\right) ; 10$ days $\left(\sum \mathbf{P}_{10}\right) ; 20$ days $\left(\sum \mathbf{P}_{20}\right) ; 40$ days $\left(\sum \mathbf{P}_{40}\right)$; 60 days $\left(\sum \mathbf{P}_{60}\right)$.

Analysis of hydrological data made it possible to correlate rainfall on the day of the event, considered as a triggering factor, and cumulative rainfall in the antecedent period, considered as predisposing factors (Crozier and Eyles, 1980). Antecedent rainfalls indeed lead to moisture and pore pressure increment within the soil. This method of analysis, among numerous ones known in literature (De Vita and Reichenbach, 1998), can utilise daily rainfall data in a simple approach, adequate for the preliminary study of these phenomena on a large scale.

Graphical relationships between $\mathrm{P}$ and cumulative rainfalls of antecedent periods $\left(1\right.$ day $=\mathrm{P}_{-1} ; 4$ days $=\sum \mathrm{P}_{5}-\mathrm{P}$; 9 days $=\sum \mathrm{P}_{10}-\mathrm{P} ; 19$ days $=\sum \mathrm{P}_{20}-\mathrm{P} ; 39$ days $=\sum \mathrm{P}_{40^{-}}$ $\mathrm{P} ; 59$ days $\left.=\sum \mathrm{P}_{60}-\mathrm{P}\right)$ have been checked. The graphical analysis show, for occurrences of debris flows of LattariSalerno Mountains, a significant lower envelope. In particular, increasing the antecedent cumulative period, the lower envelope evolves until it reaches a stabilisation for the highest antecedent periods (39 days and 59 days in Fig. 2). In these cases the lower envelope decreases until about $\mathrm{P}=$ $50 \mathrm{~mm}$, when cumulative antecedent rainfall increases, thus highlighting the strong influence of antecedent soil moisture conditions and the evapotranspiration effect. In particular, the minimum amount of cumulative rainfall necessary to soil water retention $(180 \mathrm{~mm} \div 310 \mathrm{~mm}$ ) may be approximately outlined. When cumulative antecedent rainfall is absent, the threshold value increases to $\mathrm{P}=110 \mathrm{~mm}$ (Figs. 2 and 3); moreover, this value of $24 \mathrm{~h}$ cumulative rainfall advances any intensity-duration thresholds tested for this kind of landslide in peri-vesuvian hillslopes (Moser and Hohensinn, 1983; Guadagno, 1991). From verifying graphical relationships, the lower envelope for the highest antecedent period (59 days) indicates a strong reduction of antecedent cumulative rainfall effects on thresholds values (Fig. 2) and may thus be considered as an empirical hydrological threshold generically valid for the Lattari-Salerno Mountains (Fig. 3).
Independent occurrences of daily rainfall and cumulative rainfall with values corresponding to previously mentioned thresholds are frequent in the historical series (mean period of recurrence is less than 1 year). Otherwise, occurrences of both conditions are quite low-frequency events in the rainfall historical series, with a recurrence comparable with debris flows themselves (mean period of recurrence is about 3 years).

In the same graphical relationships, a rainfall of less than $32 \mathrm{~mm}$ on the day of the event characterises occurrences of debris flows in the Sarno Mountains (except for b.3 phenomena that occurred in a geomorphological context more similar to the Salerno Mountains). Nevertheless, cumulative antecedent rainfall, though without an extraordinary total value but never lower than a threshold amount, appears marked by a homogeneous distribution. This property of rainfall sequences can be highlighted by a high value of correlation coefficient estimated on the cumulative rainfall curve, which appears almost rectilinear in these cases. Thus, the correlation coefficient may indicate, at the same total rainfall value and the same duration, the most homogeneous distribution in a sequence of rainy days (De Vita, 2000). For this reason, it can be considered a qualitatively good indicator of the best conditions for the infiltration of a rainfall sequence in medium-low permeability soils.

Rainfall sequences of the most representative landslides occurring in the Sarno Mountains have been analysed: debris flows of Palma Campania, on 22 February 1986 (b.4), and debris flows of Sarno, on 21 February 1963 (b.6). In the first case, the rainfall sequence highlights the period of 17 rainy days antecedent to the landslide, by means of a maximum correlation coefficient value of the cumulative rainfall curve $\left(R^{2}=0.993\right)$. The hydrological conditions represented by the total value of precipitation ( $>227 \mathrm{~mm}$ ) over 17 days, and the homogeneous distribution, appear only three times in the whole historical series (1919-1942; 1952-1995). Two of these cases without notice of landslide occurred in autumn, while the landslide occurred in late winter. Such evidence seems to indicate that in autumn the soil moisture and/or pore pressure are still in an early stage of recharge, thus characterising the aforesaid homogeneous rainfall sequences as insufficient for triggering landslides. The same analysis has also been conducted for the debris flows of Sarno on 21 February 1963 (b.6), showing a maximum value of correlation coefficient $\left(\mathrm{R}^{2}=0.991\right)$ of the cumulative rainfall curve for 12 days antecedent to the landslide. In this case as well, the total value of precipitation $(>100 \mathrm{~mm})$ over 12 days, and the homogeneous distribution, appear only five times in the whole historical series (1919-1942; 1952-1995). Two of these cases occurred in autumn, while another three cases (including b.6) occurred in late winter.

Such apparently different behaviour of triggering rainfall patterns between the Lattari-Salerno Mountains and the Sarno Mountains could be correlated to specific different hydrogeological features of the surficial system formed by pyroclastic cover-carbonate bedrock. Unlike the LattariSalerno Mountains, surficial aquifers of the Sarno Mountains 

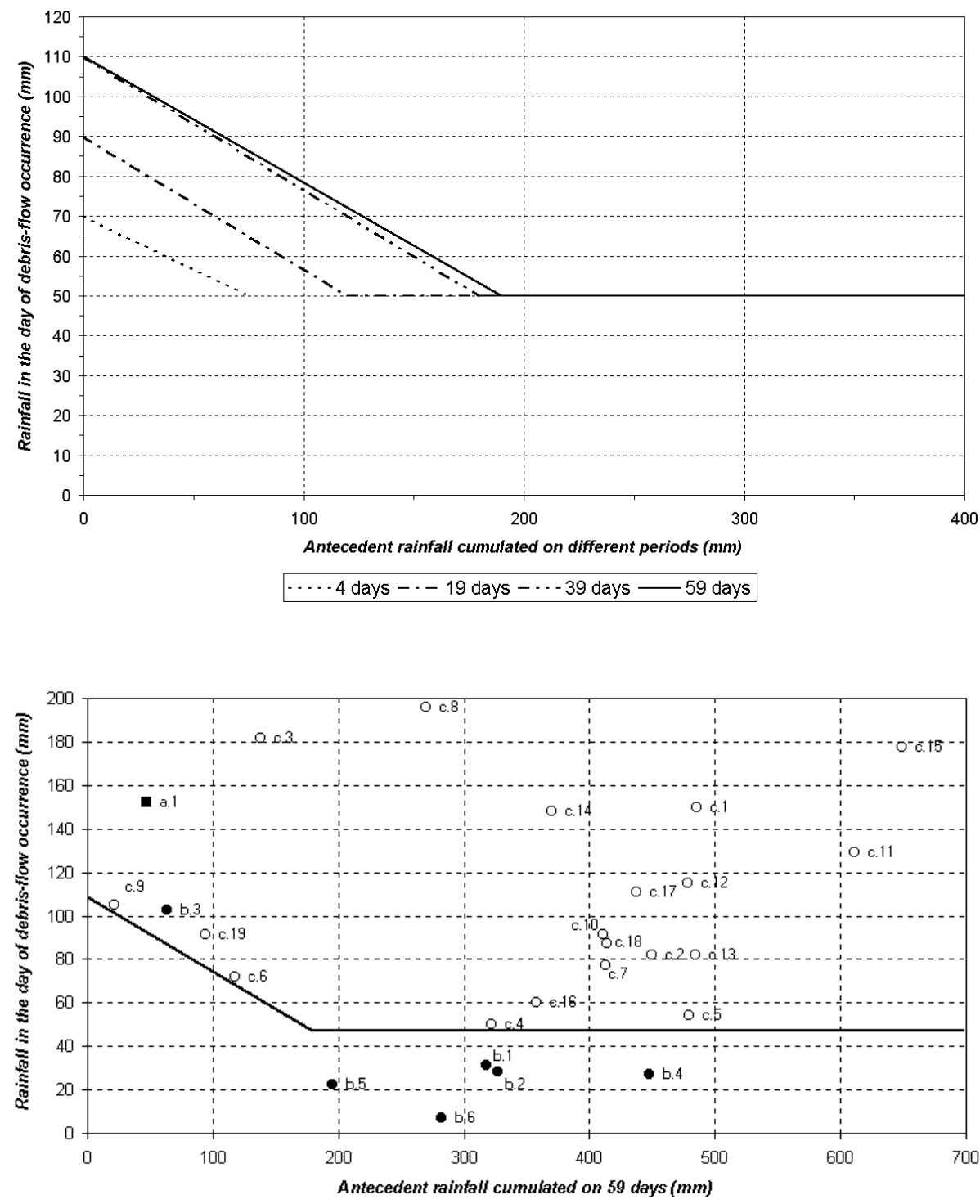

- Salerno Mountains (a)

- Sarno Mountains (b)

- Lattari Mountains (c)
Fig. 2. Lower envelopes for historical data of rainfall on the days of debris flows occurrences vs. antecedent rainfall, cumulated in different periods (4 days $=\sum \mathrm{P}_{5}-\mathrm{P} ; 19$ days $=\sum \mathrm{P}_{20}-\mathrm{P} ; 39$ days $=\sum \mathrm{P} 4_{40}-\mathrm{P} ; 59$ days $\left.=\sum \mathrm{P}_{60}-\mathrm{P}\right)$. Checking among increasing antecedent periods, the migration of the lower envelope and its stabilisation for longer antecedent periods is highlighted.
Fig. 3. Lower envelope for historical data of rainfall, on the days of debris flows occurrences $(\mathrm{P})$ vs. rainfall cumulated during 59 days $\left(\sum \mathrm{P}_{60}-\mathrm{P}\right)$. seem more predisposed to high modulation of groundwater flow. This behaviour is probably due to the thicker pyroclastic deposits in the Sarno Mountains, present in the upper part of hillslopes and in the summit flat area of tectonic-karstic depressions, related to the major proximity of these mountains to the volcano (Fig. 1).

\section{Hydrogeological investigation and interpretative models}

Hydrogeological field investigations have been performed to examine groundwater flow within the surficial zone of the Pizzo d'Alvano area (Fig. 4), affected by some landslides in May 1998. The aim of this part of the research is the definition of hydrogeological models useful in defining the conditions activating debris flows.
Investigations included: a) analysis of large-scale groundwater circulation within the carbonate ridge of Pizzo d'Alvano; b) hydraulic characterisation of the pyroclastic mantle; c) examination of rock mass discontinuities in sample areas close to the trigger point of the initial slides of May 1998.

\subsection{Methods, data and results}

A large-scale hydrogeological survey revealed two types of springs fed by the Pizzo d'Alvano ridge. The springs, located at the base of relief (between 27 and $30 \mathrm{~m}$ above s.1.), have, on the whole, an average discharge rate of $9 \mathrm{~m}^{3} / \mathrm{s}$ (Fig. 4). The base groundwater flow of the carbonate aquifer, generally very fractured and subject to karstification (average yield of $0.025 \mathrm{~m}^{3} / \mathrm{s} \times \mathrm{km}^{2}$; Celico, 1983), feed these springs. Other springs (11 identified in the studied area) are located 


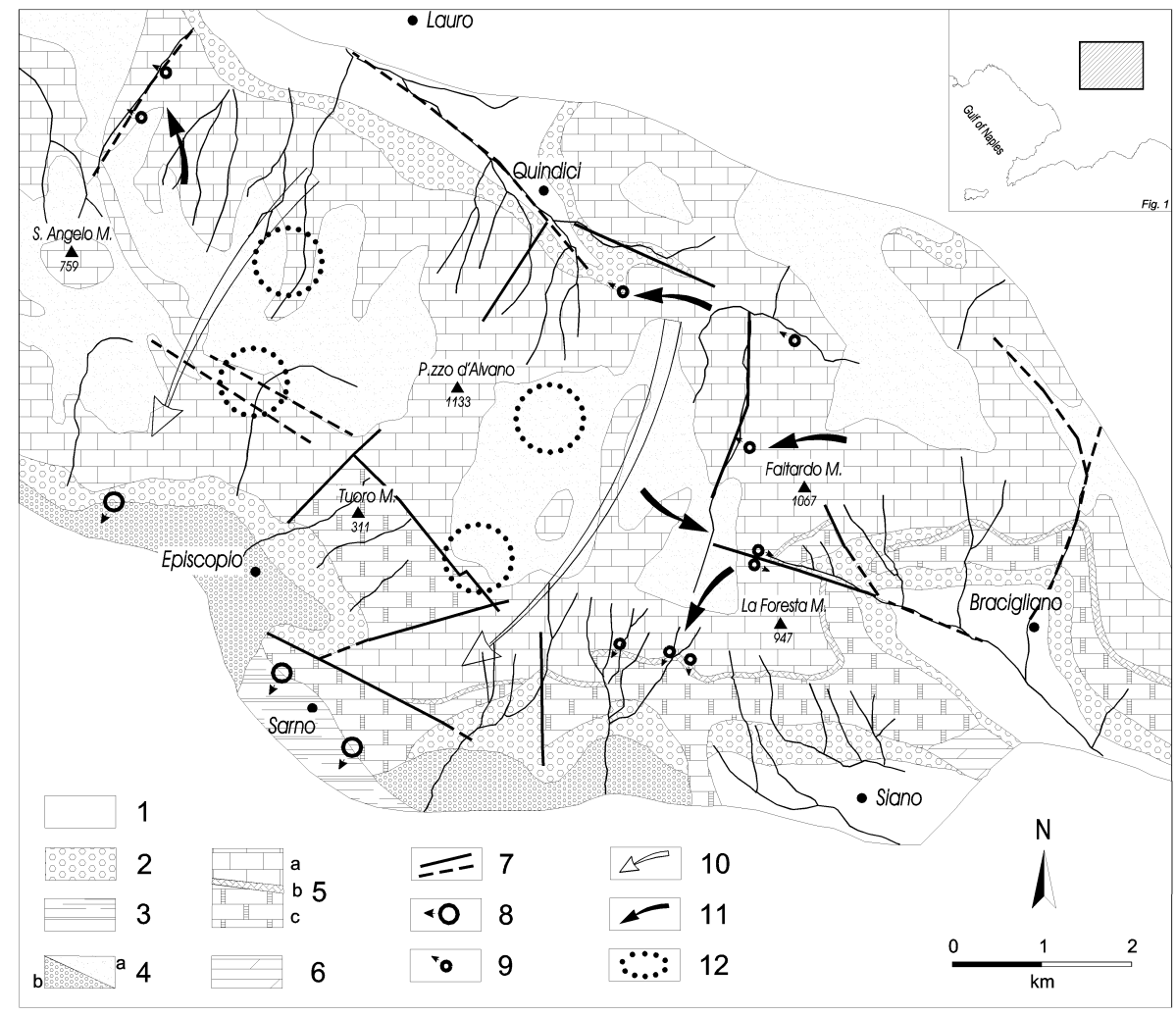

Fig. 4. Hydrogeological sketch of Pizzo d'Alvano ridge (Sarno Mountains): 1) alluvial deposits; 2) detritus and talus deposits; 3) travertine; 4a) incoherent fall pyroclastic deposits; 4b) alluvial fan constituted of debris flows deposits and limestone carbonate detritus; 5a) upper Cretaceous limestones; 5b) middle Cretaceous marl level; 5c) lower Cretaceous limestones; 6) Jurassic dolomitic limestone; 7) outcropping and buried faults; 8) springs of basal groundwater circulation; 9) springs of perched water tables circulation; 10) flows directions of basal groundwater circulation; 11) flow directions of perched water tables; 12) surveyed areas. along the slopes of the carbonate relief between 300 and $750 \mathrm{~m}$ above s.l. (Fig. 4). They have an average discharge of less than $0.010 \mathrm{~m}^{3} / \mathrm{s}$ and a large variation of outflow over the year. Only two of these springs have a discharge of more than $0.005 \mathrm{~m}^{3} / \mathrm{s}$, the remainders are seasonal springs with a discharge rate of less than $0.002 \mathrm{~m}^{3} / \mathrm{s}$.

This latter type of spring is related to the presence of perennial and seasonal perched water tables, typical of the Jurassic-Cretaceous carbonate sequence of the Southern Apennines (Civita, 1969, 1974; Civita et al., 1970, 1971,1973; Celico, 1978; Celico and de Riso, 1978).

Hydrogeological survey also revealed two types of well. The wells located at the base of the relief tap carbonate aquifer to a depth of 50-100 $\mathrm{m}$. They have a piezometric level related to spring head and a specific capacity of between $10^{-1}$ and $10^{-3} \mathrm{~m}^{2} / \mathrm{s}$. The wells located in the summit gently slope and in the closed basin on the relief have generally a reduced depth (less than $10 \mathrm{~m}$ ). They drain pyroclastic cover and they hold water only during the wet period.

Hydrogeological characterisation of the pyroclastic mantle included stratigraphic determination through 5 boreholes and 5 outcropping sections in 4 areas, some of which were near the uphill portion of landslides (Fig. 4). For 20 samples of pyroclastic deposits, granulometric curves have been determined (Fig. 5).

During this investigation phase, 30 slug tests on the first seven metres of pyroclastic cover were conducted. The method included the measurement of water level decline after injection in small diameter boreholes. Hydraulic conduc- tivity was determined by the Cedergren (1967) formula. Values of hydraulic conductivity (Fig. 6) highlight the heterogeneity of pyroclastic mantle in line with the wide granulometric range of deposits.

Initial surveys of rock mass fracturing were carried out in 9 sample sites uphill of the landslides. Hydro-structural surveys were aimed at determining hydraulic conductivity of the rock mass through the analysis of discontinuity geometry on outcropping.

Snow's theoretical model (1969) provided a basis. In this model, the conductivity of a discontinuity system is defined as a second-rank symmetric tensor, in the hypothesis of a negligible permeability of the rock matrix compared with that of the discontinuity itself. The hydraulic conductivity of a single discontinuity system is expressed by the "cubic law" and the principal components of the tensor may be defined if the average spatial orientation of the plane of the discontinuity system is known.

Survey procedure included an examination of a standard size volume of rock (approximately $100 \mathrm{~m}^{3}$ ) and at least two perpendicular rock walls. Discontinuities studied in detail were found to be "continuous", i.e. with a linear persistence greater or equal to $90 \%$ of the size of the measured plane. Spacing and opening were determined for each discontinuity orientation.

Measurements were processed according to methods proposed in the literature (Wittke, 1990). Initially, the average values of the three main parameters relating to each discontinuity system were determined. Subsequently, a hydraulic 

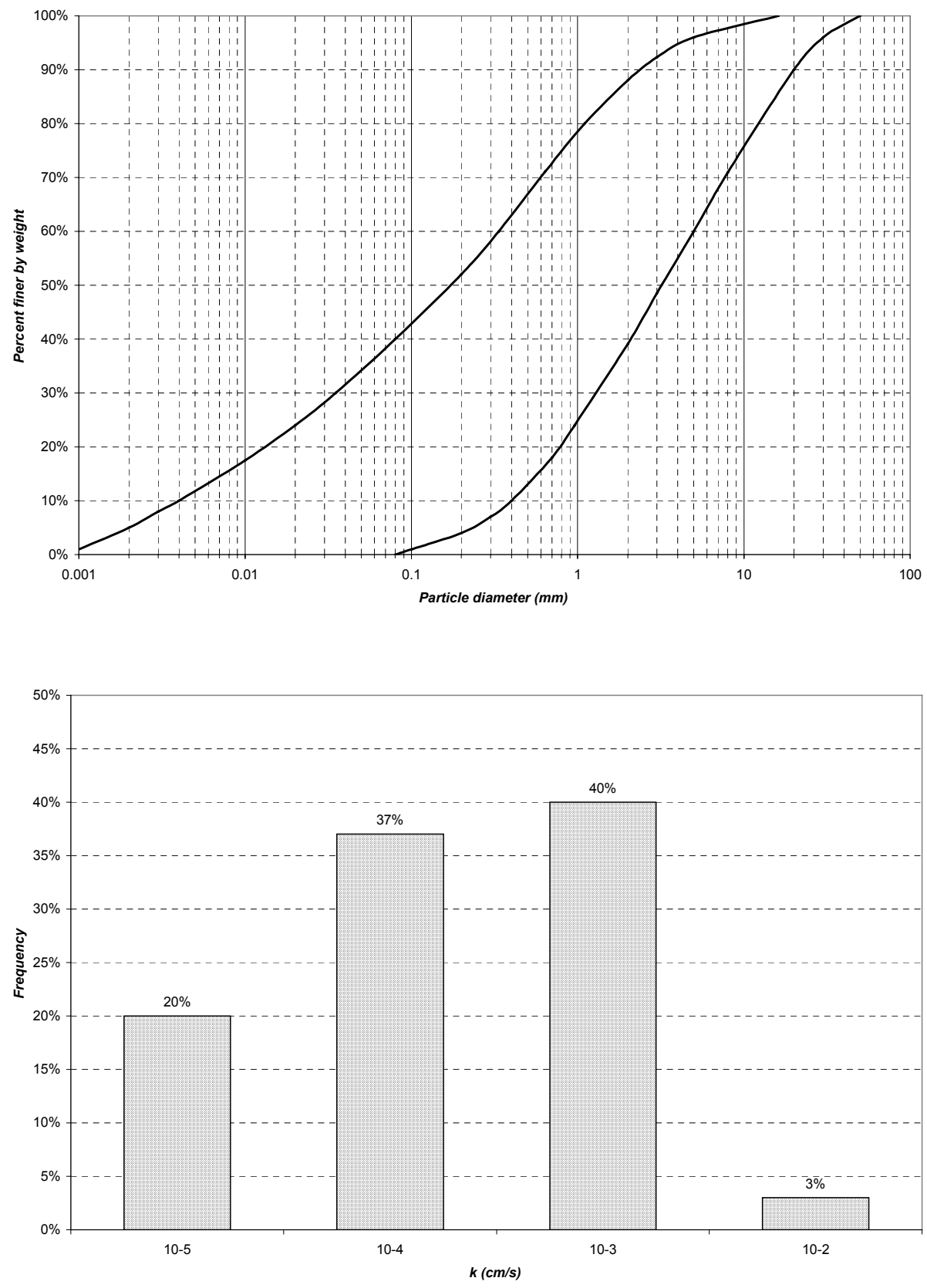

Fig. 5. Grain size distribution range for pyroclastic deposits examined.
Fig. 6. Frequency distribution of the hydraulic conductivity $(\mathrm{k})$ of the pyroclastic deposits. conductivity tensor was calculated for each system and the rock volume as a whole. The principal components of the rock mass tensor $\left(k_{x}, k_{y}\right.$ and $\left.k_{z}\right)$ were referred to a fixed coordinate system with the $y$-axis orientated north and the z-axis directed vertically upwards.

The results of computation (Table 2) highlight hydraulic heterogeneity and anisotropy of the surficial portion of carbonate bedrock. However, by simplifying the discontinuity net which affects the limestone rocks, significant differences in hydraulic conductivity are evident between the various systems of discontinuity, outcrops, and sometimes even between portions of the same outcrop.

\subsection{Discussion and hydrogeological model}

Though the information collected is by no means exhaustive, it has allowed for some preliminary considerations to be drawn regarding the complexities of recharge and flow in the uppermost layers of the Pizzo d'Alvano ridge in the aftermath of a landslide. Among these considerations, first and foremost, is that the variations in hydraulic conductivity discovered within the pyroclastic cover (from $10^{-2}$ to $10^{-5} \mathrm{~cm} / \mathrm{s}$ ), associated with long, though not heavy rainfall (as recorded by the raingauge of Lauro in the crisis period, not representative, however, of the peak rainfall affecting the mountain), may justify the origin of the water table within the carbonate covering. Furthermore, it has been 
Table 2. Principal components of hydraulic conductivity tensor of surficial portion of carbonate bedrock, surveyed in the areas showed in Fig. 4

\begin{tabular}{cccc}
\hline Outcropping & $k_{x}(\mathbf{c m} / \mathbf{s})$ & $k_{y}(\mathbf{c m} / \mathbf{s})$ & $k_{z}(\mathbf{c m} / \mathbf{s})$ \\
\hline 1 & $1.31 \times 10^{-2}$ & $1.36 \times 10^{-2}$ & $0.51 \times 10^{-2}$ \\
2 & $3.19 \times 10^{-2}$ & $2.70 \times 10^{-2}$ & $0.62 \times 10^{-2}$ \\
3 & $0.39 \times 10^{-2}$ & $0.41 \times 10^{-2}$ & $0.64 \times 10^{-2}$ \\
4 & $0.21 \times 10^{-2}$ & $0.16 \times 10^{-2}$ & $0.12 \times 10^{-2}$ \\
5 & $7.40 \times 10^{-2}$ & $6.27 \times 10^{-2}$ & $8.94 \times 10^{-2}$ \\
6 & $3.36 \times 10^{-6}$ & $3.36 \times 10^{-6}$ & $2.30 \times 10^{-9}$ \\
7 & $2.52 \times 10^{-2}$ & $8.50 \times 10^{-2}$ & $10.30 \times 10^{-2}$ \\
8 & $7.18 \times 10^{-2}$ & $3.47 \times 10^{-2}$ & $7.26 \times 10^{-2}$ \\
9 & $1.03 \times 10^{-2}$ & $6.68 \times 10^{-2}$ & $7.48 \times 10^{-2}$ \\
\hline
\end{tabular}

found that near some areas of landslide activity, the carbonate rock may be relatively less permeable than its pyroclastic covering, when it is characterised by a reduced thickness and where the grain fraction is coarser. This contrast in permeability and those linked exclusively to the heterogeneity $\left(k=10^{-1}-10^{-9} \mathrm{~cm} / \mathrm{s}\right)$ and anisotropy $\left(k_{x} \neq k_{y} \neq k_{z}\right)$ of the rock mass would seem to suggest further reasons that are responsible for the formation of occasional water tables within the uppermost portion of the rock mass.

These conclusions come from considerations on a onedimensional vertical system that includes: i) moisture content of pyroclastic mantle antecedent to the first days of May 1998 also deduced from an evaluation of infiltration and evapotranspiration rates (Celico et al., 2000); ii) relationship (Rubin and Steinhardt, 1963; Freeze, 1974) between rainfall intensity $\left(1.42 \times 10^{-4} \mathrm{~cm} / \mathrm{s}\right.$ at raingauge of Lauro) and duration of storm $(29 \mathrm{~h})$, time of overland flow and saturated hydraulic conductivity of pyroclastic deposits; iii) hydrostratigraphy determined near the landslides upslope.

Water table formation within the uppermost portion of the pyroclastic-carbonate system implies the increase in pore pressure along the failure planes that may condition the stability of the pyroclastic cover involved in certain disastrous events. In other words, the resulting rise of perched water tables computed in the investigated areas varies between 1 and $3 \mathrm{~m}$; this variation is sufficient to trigger the landslides when considering the topography of slope and the cohesion and angle of internal friction of pyroclastic deposits (Celico et al., 1986).

The investigations conducted near some areas of landslides give rise to at least three hydrogeological models, that may be useful in future detailed slope stability analysis. A first observed model is one which includes a pyroclastic mantle thickness exceeding some metres and an initial failure within the same mantle overlying the limestone substratum. A hydrogeological profile has been distinguished, characterised by a first layer with permeability greater or equal to $10^{-3} \mathrm{~cm} / \mathrm{s}$, followed by reduced permeability of less than $10^{-4} \mathrm{~cm} / \mathrm{s}$ at some two metres of depth.
In this case, even rainfall of a reduced quantity and intensity, such as that recorded at Lauro during the crisis period (1.42 $\times 10^{-4} \mathrm{~cm} / \mathrm{s}$ ), could have given rise to a strong variation in pore pressure of the uppermost strata, lying within a medium close to saturation.

A second possible model is that of a poorly fractured carbonate substratum $\left(\mathrm{K} \leq 10^{-4} \mathrm{~cm} / \mathrm{s}\right)$ lying beneath a slight covering of pyroclastic deposits, belonging to the uppermost layer, and by coarser and permeable levels $\left(\mathrm{K} \geq 10^{-3} \mathrm{~cm} / \mathrm{s}\right)$. In this case, a more considerable variation of the pore pressure in the carbonate substratum might occur, even with the same weather conditions as those prevalent in May 1998.

A third model suggests a thin permeable pyroclastic mantle overlying the carbonate substratum, characterised by a strong variation in permeability vertically in the first few metres below the surface. What follows is a vertical stratification permeable type $\mathrm{K} 1 \geq \mathrm{K} 2 \geq \mathrm{K} 3$, which could give rise to a rapid reduction in infiltration capacity in the third stratum, even during less intense rainfall but in a period in which the surface pyroclastic stratum is close to saturation. Consequently, significant variations in pore pressure may occur in the second stratum, which might affect the stability of the pyroclastic mantle.

\section{Conclusions}

The analysis of the rainfall pattern highlighted empirical hydrological thresholds, estimated as lower envelopes of historical rainfall data, related to each occurrence of debris flow. These critical conditions seem to differentiate the LattariSalerno Mountains from the Sarno Mountains. The first case is characterised by rainfall on the day of the debris flow occurrence $\geq 50 \mathrm{~mm}$ and significant cumulated rainfall in the antecedent periods. Otherwise, in the second case, rainfall on the day of the debris flow occurrence was $\leq 32 \mathrm{~mm}$ and cumulated rainfall in the antecedent periods appeared relevant and was characterised by a very homogeneous distribution in a long series of rainy days (namely low intensity but prolonged rainfall sequences). In both cases, the threshold conditions appear as rare occurrences from rainfall historical series. In particular, estimating the ratio between cases with landslides and cases without landslides, a high frequency of landslide occurrences correspond to the mentioned threshold conditions. However, the frequency could be higher since landslides, which caused heavy damage to towns or roads, were only noticed in newspapers.

The hydrogeological investigations carried out on the Sarno Mountains highlighted the coexistence of more surficial hydrogeological models. In some sample areas, close to the trigger areas of the landslides of May 1998, strong variations in hydraulic conductivity have been found in the first few metres below the surface (up to three-order size). These permeability variations are due to: the heterogeneity of the pyroclastic deposits; the difference in hydraulic conductivity between the pyroclastic mantle and the low fractured carbonate bedrock; the variation in fracturing degree of 
the upper carbonate bedrock. The variations of the hydraulic conductivity would seem to justify the increase in pore pressure during rainfalls, which might affect the stability of the pyroclastic mantle. This may occur after the recharge period of surficial aquifers and also in periods of less than heavy rainfall.

What emerges by earlier discussion is a definition, in a preliminary way, of the hydrological and hydrogeological conditions leading to the triggering of debris flows. Further research will be oriented to increase experimental knowledge of the local hydrogeological conditions, also by monitoring the pore pressure in the surficial layers in relation to rainfall inputs. Thus, improved hydrogeological knowledge of the Lattari-Salerno Mountains and the Sarno Mountains is necessary in order to further justify different triggering hydrological conditions.

\section{References}

Calcaterra, D., Santo, A., de Riso, R., Budetta, P., Di Crescenzo, G., Franco, I., Galietta, G., Iovinelli, R., Napolitano, P., and Palma, B.: Fenomeni franosi connessi all'evento pluviometrico del gennaio 1997 in Penisola Sorrentina-Monti Lattari: primo contributo, IX Congresso O.N.G., Roma, 1997.

Cascini, L. and Versace, P.: Eventi pluviometrici e movimenti franosi, Associazione Geotecnica Italiana XVI Convegno Nazionale di Geotecnica Bologna 14-16 maggio, 1986.

Cedergren, H. R.: Seepage, Drainage and Flow Nets, John Wiley and Sons, New York, 1967.

Celico, P.: Schema idrogeologico dell'Appennino carbonatico centro-meridionale, Memorie e Note dell'Istituto di Geolologia Applicata di Napoli, 14, Napoli, 1978.

Celico, P.: Le risorse idriche sotterranee dell'Appennino carbonatico centro-meridionale, Idrotecnica, 1, 3-17, 1983.

Celico, P., Aquino, S., Esposito, L., and Piscopo, V.: Problematiche idrogeologiche connesse con i fenomeni di instabilità delle coltri piroclastiche della dorsale di Pizzo d'Alvano (Campania), Quaderni di Geologia Applicata, 7-2, 2000.

Celico, P. and de Riso, R.: Il ruolo della valle Caudina nell'idrogeologia del Casertano e del Sarnese, Memorie e Note dell'Istituto di Geolologia Applicata di Napoli, 14, Napoli, 1978.

Celico, P. and Guadagno, F. M.: L'instabilità delle coltri piroclastiche delle dorsali carbonatiche in Campania: attuali conoscenze, Quaderni di Geologia Applicata, 5-1, 75-133, Bologna, 1998.

Celico, P., Guadagno, F. M., Vallario, A.: Proposta di un modello interpretativo per lo studio delle frane nei terreni piroclastici, $\mathrm{Ge}-$ ologia Applicata e Idrogeologia, 22, Bari, 1986.

Civita, M.: Idrogeologia del Massiccio del Terminio-Tuoro (Campania). Memorie e Note dell'Istituto di Geolologia Applicata di Napoli, 11, 92, Napoli, 1969.

Civita, M.: Osservazioni idrogeologiche nel versante sudoccidentale del massiccio del Cervati per la captazione delle Fistole del Faraone. Memorie e Note dell'Istituto di Geolologia Applicata di Napoli, 13, 36, Napoli, 1974.

Civita, M., de Medici, G. B., de Riso, R., Nicotera, P., and Nota d'Elogio, E.: Carta Idrogeologica della Campania nordoccidentale e relativa memoria illustrativa. Atti $1^{\circ}$ Conv. Int.
Acque Sotterranee, Palermo, 1973.

Civita, M., de Riso, R., Lucini, P., and Nota d'Elogio, E.: Studio delle condizioni di stabilità dei terreni della Penisola Sorrentina (Campania), Geologia Applicata e Idrogeologia, 10, 129-188, Bari, 1975.

Civita, M., de Riso, R., Vallario, A., and de Masi, R.: Possibilità di rinvenimento di nuove fonti di approvvigionamento idrico nella media valle dell'Isclero e nella bassa valle del Calore (Campania), Geologia Tecnica, 6, 1970.

Civita, M., de Riso, R., Vallario, A., and de Masi, R.: Idrogeologia del massiccio del Taburno-Camposauro (Campania), Memorie della Società Geolologica d'Italia, 10, 1971.

Civita, M. and Lucini, P.: Sulla franosità della zona nordoccidentale della Penisola Sorrentina (Campania), Memorie e Note dell'Istituto di Geologia Applicata, 10, Napoli, 1968.

Crozier, M. J. and Eyles, R. J.: Assessing the probability of rapid mass movement, III Australian-New Zealand Conf. On Geomechanics, 2, 1980.

De Falco, M., de Riso, R., and Ducci, D.: La piovosità della Penisola Sorrentina e dei M.ti Lattari in relazione all'evento del gennaio 1997, Memorie dell'Istituto di Geologia Applicata Facoltà di Ingegneria - Univ. di Napoli "Federico II", pubbl. 372, Napoli, 1997.

Del Prete, M., Guadagno, F. M., and Hawkins, A. B.: Preliminary Report on the Landslides of \% May 1998, Campania, Southern Italy, Bull. Eng. Geol. and Env., 57, 1998.

De Riso, R. and Nota d'Elogio, E.: Sulla franosit della zona sud-occidentale della Penisola Sorrentina, Memorie e Note dell'Istituto di Geologia Applicata, 12, Napoli, 1973.

De Vita, P.: Fenomeni di instabilità delle coperture piroclastiche dei Monti Lattari, di Sarno e di Salerno (Campania) ed analisi degli eventi pluviometrici determinanti, Quaderni di Geologia Applicata, 7-2, 2000.

De Vita, P. and Reichenbach, P.: Rainfall-triggered landslides: a references list, Congress of European Geophysical Society 1996 Enviromental Geology, 35, 219-233, 1998.

Freeze, R. A.: Streamflow generation, Rev. Geophys. Space Phys., 12, 627-647, 1974.

Guadagno, F. M.: Debris flows in the Campanian volcaniclastic soils (Southern Italy), Slope stability engineering developments and applications, 15-18 April 1991, Isle of Wight, 1991.

Guadagno, F. M., Palmieri, M., Siviero, V., and Vallario, A.: La frana di Palma Campania, Geologia Tecnica, 4, 18-29, Roma, 1988.

Guida, M., Iaccarino, G., and Vallario, A.: Alcune considerazioni sui fenomeni di dissesto e sulla difesa del suolo nella Penisola Sorrentina, Geologia Tecnica, 2, 120-128, Roma, 1974.

Guzzetti, F., Cardinali, M., and Reichenbach, P.: The AVI Project: A Bibliographical and Archive Inventory of Landslides and Floods in Italy, Enviromental Management, 18, 4, 1994.

Moser, M. and Hohensinn, F.: Geothecnical aspects of soil slips in Alpine Regions - Eng. Geol. 19, 1983.

Rubin, J. and Steinhardt, R.: Soil water relations during rain infiltration: I. Theory, Soil Sci. Soc. Amer. Proc., 27, 246-251, 1963.

Snow, D. T.: Anisotropic permeability of fractured media, Water Res. Research, 5/6, 1273-1289, 1969.

Wittke, W.: Rock Mechanics, Springer-Verlag, Berlin Heidelberg, 1990. 